Poznańskie Studia Teologiczne 30(2016), s. 191-215.

doi: $10.14746 /$ pst.2016.30.09

Janusz Nawrot ${ }^{1}$

Uniwersytet im. Adama Mickiewicza w Poznaniu

Wydział Teologiczny

\title{
Teologiczny obraz twierdzy jerozolimskiej w 1 Mch 1,33-38 i jej oblężenie przez wojska Judy w 4,41 oraz 6,18-20
}

Poniższy artykuł dotyczy epizodu powstania machabejskiego, który rozgrywał się zarówno przed śmiercią Antiocha IV Epifanesa i w niedługim czasie po niej. Okazuje się, że nawet po śmierci władcy imperium sytuacja w prowincji judzkiej nadal była napięta. Nieustanne ataki na twierdzę jerozolimską świadczą o docenianiu przez powstańców znaczenia akry w procesie stałego nękania narodu wybranego. Rola ta zostanie uwypuklona w pierwszej części prezentowanego w opracowaniu materiału na podstawie poruszonych w nim tekstów 1,33 oraz 34-38. Natomiast nadrzędnym celem prezentacji jest próba odpowiedzi na pytanie autora księgi, dlaczego Judzie Machabeuszowi, naczelnemu wodzowi insurekcji - mimo jego, jak się zdawało, doskonałej niemal wierności Bogu, a także licznych sprzyjających okoliczności - nie udało się zdobyć twierdzy². Proponowany artykuł wpisuje się w słabo jeszcze opisywaną przez badaczy problematykę Pierwszej Księgi Machabejskiej, szerzej zaś w ogóle ksiąg deuterokanonicznych, znacznie częściej pomijanych w omówieniach egzegetycznych niż dzieła Biblii Hebrajskiej.

\section{Teologia zamku jerozolimskiego według 1,33}

Zanim będzie można przejść do prezentacji teologii natchnionego autora księgi, wydaje się konieczne przynajmniej szkicowe zaznajomienie czytelnika $\mathrm{z}$ istnieniem i funkcjonowaniem twierdzy jerozolimskiej, czyli a kry, jej zadaniami i wpływem na życie mieszkańców stolicy. Łatwiej wówczas będzie można zrozumieć konieczność prowadzenia walk o likwidację zamku jako fortecy po-

\footnotetext{
${ }^{1}$ Janusz Nawrot, kapłan archidiecezji poznańskiej, od 2013 profesor tytularny, zatrudniony w Zakładzie Nauk Biblijnych.

${ }^{2} \mathrm{Z}$ historycznego punktu widzenia o jego działaniach wojennych, por. J. Nawrot, Pierwsza Księga Machabejska, Częstochowa 2016, s. 107-120 oraz tenże: Wyprawa Antiocha IV na wschód imperium $w$ teologicznej relacji 1 Mch 6, 1-4, SG 29(2015), s. 119-141. Problem ten nie został zadowalająco wyłożony w cytowanym komentarzu, dlatego w obecnym omówieniu autor pragnie dopowiedzieć kilka kwestii.
} 
gańskiej, kontrolującej całość codziennej egzystencji, zwłaszcza politycznej i religijnej miasta. Oddziaływanie twierdzy nie jest jeszcze wystarczająco zbadane, a trudności, które dotyczą nawet jej lokalizacji, nie ułatwiają naukowcom dojścia do wyznaczonych celów. Ukazując bardzo syntetycznie rolę i zadania cytadeli w mieście, można je scharakteryzować następująco:

- zamek obronny założony w celu kontrolowania życia religijnego w Jerozolimie

- garnizon złożony z pogan ${ }^{3}$ oraz Żydów - odszczepieńców od prawa Mojżeszowego ${ }^{4}$

- usytuowanie w pobliżu świątyni ${ }^{5}$

- centrum wpływów prohelleńskich w prowincji judejskiej

- stałe zagrożenie dla funkcjonowania kultu Boga Izraela i wszelkich ruchów niepodległościowych.

Wzmiankując budowę samego zamku w świętym mieście, w 1,33 hagiograf koncentruje się na teologicznym aspekcie jego konstruowania przez pogan. Oto w 2 Bas $5,9^{6}$ biblijny autor napomknął o przejęciu starej twierdzy Jebuzytów przez Dawida po zdobyciu Jerozolimy. Cytadelę zaś określił mianem periochē, czyli 'miejsce okalające, znajdujące się wokół', co w myśl 5,7 odnosi się do Syjonu, zdobytego przez króla Judy. Kolejne teksty biblijne Septuaginty charakteryzują je jako miejsce przede wszystkim obronne, dające schronienie zwłaszcza w wypadku ataku przeciwnika ${ }^{7}$, jako ogrodzenie lub fortyfikację ${ }^{8}$. Ważna jest

${ }^{3}$ Diodor pisze o takiej samej praktyce ustanawiania straży w twierdzach jeszcze za czasów Aleksandra Wielkiego, chociaż nie używa terminologii podobnej do Józefa: tēn men akran paredōke têrein [...] systēsas Makedonas stratiōtas, 'przekazał straż nad twierdzą [...], przydzielając macedońskich żołnierzy' (BH XVII, 64.5). Słowa te wskazują wyraźnie, że strategiczne punkty kontroli nad regionem obsadzane były własnymi wojskami, lojalnymi wobec przełożonych i władców. Józef Flawiusz pisze wprost o frouran Makedonikēn, 'załodze macedońskiej' w twierdzy (Ant. XII, 5.4.252).

${ }^{4}$ Ten punkt niewątpliwie znajduje się w centrum uwagi hagiografa, który w 1, 33 definiuje ich mianem ethnos hamartōlon, 'naród grzeszny' oraz andras paranomous, 'ludzi nieprawych', co może odnosić zarówno do pogan, jak i Żydów, apostatów od prawa. Zastosowane przez pisarza biblijnego nazewnictwo służy ocenie i kieruje uwagę czytelnika nie na pochodzenie etniczne, lecz sposób postępowania wobec potencjalnych ofiar oraz stosunek do obowiązujących w regionie praw, w tym wypadku oczywiście praw religijnych narodu żydowskiego. Tak więc hamartōloi to z definicji poganie, podczas gdy paranomoi to Żydzi odstępujący od ojczystego prawa.

${ }^{5}$ Szerzej na ten temat $\mathrm{z}$ uwzględnionymi hipotezami umiejscowienia, por. m.in. Y. Tsafrir, The Location of the Seleucid Akra in Jerusalem, "Yad Yitzak Ben-Zwi" 14(1980), s. 17-40; B. Mazar, The Mountain of the Lord, Garden City 1975, s. 216-217; B.Z. Loria, The Location of the AkraNorth of the Temple Mount, "Yad Yitzak Ben-Zwi" 18(1981), s. 31-40.

${ }^{6}$ Skróty zaznaczone pismem pochyłym odnoszą się do kanonicznych biblijnych ksiag Septuaginty, według powszechnie przyjętych reguł: 1 Bas = 1 Ksiegga Samuela, 2 Bas = 2 Księga Samuela, 3 Bas = 1 Księga Królewska, 4 Bas = 2 Księga Królewska, Ier = Księga Jeremiasza, 2 Ezd = Księga Ezdrasza (1-10) i Nehemiasza (1-13 = 2 Ezd 10-23), 1 Par = 1 Księga Kronik, 2 Par = 2 Księga Kronik, $P s=$ Księga Psalmów.

${ }^{7}$ W sensie oblężenia, por. 4 Bas 24,10; 25,2; 2 Par 32,10; Za 12,2; Jr 19,9; Ez 4,2.

${ }^{8}$ Por. 2 Bas 5,17; 23,14; 1 Par 11,5.7.16; Ps 30,22; 59,11; 107,11; Ier 28,30. 
tu jednak uwaga, że przyszła stolica Izraela zdobyta została przez ulubieńca Bożego, wyróżniającego się wiernością Bogu przymierza, który sam postanowił uczynić z miasta także swoją siedzibę, uznając je za symbol swej opieki nad całym ludem. W tym świetle obecne działania pogan fortyfikujących stolicę narodu wybranego należy uznać za całkowite odwrócenie sytuacji sprzed wieków zarówno pod względem historycznym ${ }^{10}$, jak i teologicznym, jako znak opuszczenia ludu przez jego Boga. Osamotnienie zaś skutkuje natychmiastowym triumfem pogan nad Żydami, jak to niegdyś miało miejsce w wielu starciach między Izraelitami a innowiercami, gdy pierwsi przegrywali właśnie z racji swego odstępstwa od przymierza ${ }^{11}$. Nie ma wątpliwości, że sukcesy odnoszone przez współczesnych sobie pogan hagiograf interpretuje w tym samym kluczu. Warto jeszcze dodać, że wiele wieków później Flawiusz właśnie to, co hagiograf określił mianem periochē, nazwał już wprost akra, dodając, że odkąd Dawid zamieszkał w świętym mieście, wszystko układało się coraz pomyślniej dzięki opatrzności Boga, który czuwał nad nim oraz dbał, by cały lud był coraz liczniejszy (Ant. 7.3.2.65). Także więc w tym świetle triumf pogan należy uznać za wynik braku wierności ludu wobec przymierza ${ }^{12}$.

Co się jednak dzieje z ludem w świetle teologii Starego Testamentu? Otóż wraz z przejęciem miasta przez żołnierzy seleuckich Żydzi de facto przestają być ludem Pana, co dotychczas było wyznacznikiem ich tożsamości. Nie mając swego miasta, upodabniają się do wielu innych, niewielkich nacji ogromnego imperium. Po utracie swej stolicy, przede wszystkim jako miejsca wyjątkowego kultu Bożego $^{13}$, Żydzi zaczynają być traktowani jako cząstka pogańskiej całości. Doprowadzili do tego, co prawda, przede wszystkim odstępcy od przymierza i pra-

${ }^{9}$ Co widać szczególnie wyraźnie w psalmach, por. m.in. 2,6;9,12; 19,3; 47,3; 49,2; 50,20; 68,$36 ; 73,2 ; 75,3 ; 77,68 ; 83,8 ; 86,2.5$ itd. Szerzej jest to efekt wierności Bogu przymierza, wyrażony w Biblii Hebrajskiej czasownikami šamā oraz 'āsâ, zwłaszcza w nakazach wypowiedzianych przez Mojżesza w imieniu Boga, por. J. Nawrot, Teologiczne uzasadnienie wierności przymierzu, s. 6-13.

${ }^{10}$ Por. J. Nawrot, Pierwsza Księga Machabejska, dz. cyt., s. 363-364.

${ }^{11} \mathrm{~W}$ pełni realizuje się wówczas zapowiedź Kpł 26,14-33 o całym zasobie kar, jakie Bóg zastosuje wobec swojego niewiernego ludu. Szczególną rolę odgrywa w. 25 stwierdzający, że Izraelici wydani zostaną w ręce (paradothēsesthe eis cheiras) pogańskich nieprzyjaciół, por. J. Milgrom, Leviticus 23-36, New York-London-Toronto-Sydney-Auckland, s. 2304-2323. Kara ta pojawia się w kontekście wszystkich kar zsyłanych przez rozgniewanego Boga, obok zarazy, głodu i dzikich zwierząt. Kolejne stwierdzenia tego typu można odnaleźć m.in. w Sdz 2,14; 1 Bas 28,19; 4 Bas 21,14, 2 Par 25,20, itd.

${ }_{12}$ Widomym znakiem tej wierności jest pozytywny aspekt gniewu oraz zazdrości o prawo Boże, stanowiący nieodzowny przejaw gorliwości i dbałości o właściwą relację między Bogiem a Jego ludem na przykładzie wybranych postaci historii Izraela, por. J. Nawrot, qin'â jako pozytywna motywacja ludzkiego działania w Starym Testamencie, SG 24(2010), s. 43-53.

${ }^{13}$ A także przekonania o nienaruszalności Syjonu, wyrażone w Iz 38,6; Ps 132,11.13.18, por. omówienie N.R. Bowen, Ezekiel, w: The Oxford Encyclopedia of the Books of the Bible, t. 1, red. M.D. Coogan, Oxford 2011, s. 293. 
wa, wywodzący się ze środowisk kapłańskich i urzędniczych, gotowi w imię partykularnych interesów swych grup społecznych zdradzić całość narodu, tradycji i własnej religii (w. 11-15). Jednak sam lud nie jest tu bez winy, ponieważ nie potrafiąc lub nie chcąc się przeciwstawić ich działaniom, w ogóle dopuścił do takiej sytuacji ${ }^{14}$. W tym kontekście nie może dziwić brak reakcji ze strony Boga na położenie Jego ludu i zgoda na to, by poganie zawładnęli stolicą. Powtarza się jedynie sytuacja znana z przeszłości, z której jednak lud nie wyniósł konkretnych korzyści, ponieważ pozostaje w opozycji wobec swego Boga ${ }^{15}$. Obecna kondycja narodu pozostaje w opozycji do sytuacji powracających z niewoli babilońskiej Żydów, którzy odbudowali (ōkodomēsan) swą zniszczoną stolicę (2 Ezd 13.1.3.13) ${ }^{16}$. Ten sam czasownik został użyty w 1 Mch 1,33 do określenia prac przedsiębranych przez pogan budujących (ōkodomēsan) zamek w mieście świętym. Po powrocie z niewoli babilońskiej imigranci żydowscy odrzucili nawet pomoc ofiarowaną przez spokrewnionych z nimi Samarytan, wiedząc, że sami muszą odbudowywać swą stolicę. Obecnie zajmują się tym wyłącznie poganie, co oznacza, że Bóg z powodu odrzucenia Jego prawa i przymierza przez lud całkowicie poddał swe miasto $\mathrm{w}$ ich zarząd. W ten sposób następuje stopniowa, lecz nieuchronna degradacja nie tylko materialnych zasobów narodu wybranego, lecz przede wszystkim możliwości duchowych, stanowiących przecież sedno siły moralnej i religijnej ludu. Już Jeremiasz zapowiadał, że z racji niewierności miasto zostanie zniszczone. $Z$ właściwą sobie emfazą prorok $\mathrm{w}$ imieniu Boga oznajmiał, że od dnia, w którym Izraelici zbudowali (ōkodomēsan) ${ }^{17}$ swą stolicę, stała się ona symbolem zaprzaństwa, oporu przeciw swemu Bogu, co

\footnotetext{
${ }^{14} \mathrm{Na}$ poziomie historycznym oraz teologicznym warto byłoby prześledzić przyczyny całkowitego braku pośredników między narodem wybranym a jego Bogiem; rolę tę w starożytności Izraela odgrywała starszyzna ludu. Mogłaby ona stanowić znakomitą przeciwwagę dla obecnie działającej arystokracji kapłańskiej, sprzeniewierzającej się swym zadaniom, por. J. Nawrot, Jakq role odgrywaja starsi Izraela w tekstach przedstawiajacych epoke Mojżesza, PST 27(2013), s. 117-138.

${ }^{15}$ Sytuację tę opisuje tekst Ez 10,18, wspominając o odejściu chwały Boga ze świątyni napełnionej bałwochwalczym plugastwem. Opuszczenie domu Bożego przez jego Gospodarza oznacza wydanie go na pastwę zbliżających się wojsk babilońskich, dokonujących profanacji i zniszczenia wszelkich oznak kultu Bożego, por. D.I. Block, The Book of Ezekiel, Grand Rapids-Cambridge, s. 326. Natomiast w szerszym sensie chodzi wyraźnie o grzech jako nieposłuszeństwo Bożemu słowu, tak mocno obecny w historii narodu wybranego. Swego czasu wspominał o tym również papież Benedykt XVI w adhortacji Verbum Domini 26, por. omówienie egzegetyczne J. Nawrot, Miejsce $i$ rola Starego Testamentu $w$ adhortacji Benedykta XVI Verbum Domini, PST 26(2012), s. $72-74$.

${ }^{16}$ Jako wynik stopniowego poprawiania się sytuacji w prowincji oraz realizacji starotestamentowych zapowiedzi podkreślających wartość gorliwości o wierność prawu Bożemu, por. J. Nawrot, qin'â jako pozytywna motywacja ludzkiego działania w Starym Testamencie, dz. cyt., s. 56-58.

${ }^{17}$ Znamienna jest tutaj wyrocznia Oz 8,14 stwierdzająca, że Izraelici, zapominając o Tym, który ich uczynił, samodzielnie pobudowali (ōkodomēsan) święte miejsca dedykowane bożkom, zaś Juda napełniła się obwarowanymi miastami - wyraźnymi znamionami z jednej strony odejścia od swego Boga, z drugiej wyrazem pychy, czyli pokładania ufności we własnych dziełach. Spotka się
} 
spowoduje, że oddali (apallaksai) ${ }^{18}$ On je od swego oblicza $(\operatorname{Ier} 39,31)^{19}$. W czasach powstania machabejskiego żydowscy zwolennicy kolaboracji z imperium seleuckim tworzyli nową jakościowo sytuację w Ziemi Obiecanej, dopuszczając się bałwochwalstwa i odrzucając swego Boga poprzez stawianie na obce mocarstwa.

Kolejnym etapem wzmocnienia obecności pogan w Jerozolimie było odbudowanie przez nich murów okalających miasto, przedstawianych zwykle w Biblii jako wyraz jego niezależności ${ }^{20}$. Jednak miały one takie znaczenie tylko wtedy, gdy w mieście żyli wyłącznie ludzie wierni Bogu. Tymczasem prawdopodobnie większość mieszkańców Jerozolimy to już albo poganie, albo zwolennicy hellenizacji. Dlatego nowymi murami otoczono raczej jedynie tę część miasta, w której zamieszkali ci właśnie ludzie. Obejmowały one również samą cytadelę i przylegające do niej tereny, dzięki czemu konstrukcja miała stać się niedostępna dla zwolenników powstania i wierności dawnym obyczajom. Pozwalało to ponadto stale kontrolować życie w całym mieście, czemu służyć miało organizowanie wypadów terroryzujących mieszkańców i likwidacja ewentualnych prób ich powstania przeciw okupantom ${ }^{21}$. Wielkość murów (teichei megalō kai ochyrō) otaczających jerozolimską akrę jest podobna do dawniejszych, które przed zajęciem Kanaanu musieli sforsować Izraelici powracający z niewoli egipskiej (poleis ochyrai teteichismenai kai megalai, Lb 13,2822; poleis ochyrai kai megalai, Joz $14,12^{23}$ ). Oba podane teksty świadczą o tym, że podczas zdobywania miast decy-

to z oczywistą reakcją Boga, który całkowicie zniszczy te właśnie wytwory rąk ludzkich, aby odnowić świadomość, że naród wybrany zawsze zależny jest od swego Stwórcy, por. D.A. Garrett, Hosea - Joel, NNIV NAC 29, Nashville 1997, s. 188.

${ }^{18}$ W prawniczym tekście Wj 19,22 Pan żąda, by kapłani nie zbliżali się do Niego w stanie nieczystości rytualnej, gdyż w przeciwnym razie On sam oddali (apallaksē) się od nich i ludu. Autor natchniony akcentuje tu niemożność łączenia zawinionej nieczystości kultycznej ze świętością Boga, por. W.H.C. Propp, Exodus 19-40. A New Translation with Introduction and Commentary, AB 2A, New York-London-Toronto-Sydney-Auckland 2006, s. 165-166. Tym bardziej niemożliwy jest zauważony w tekście Księgi Jeremiasza jakikolwiek związek między tą świętością a brudem natury moralnej, zawsze stanowiącym fundament wykroczeń natury kultycznej.

${ }^{19}$ Por. J.A. Thompson, The Book of Jeremiah, NICOT, Grand Rapids 1980, s. 594.

${ }^{20}$ Por. m.in. 1 Mch 10,11.45; 13,33; 16,23; 2 Ezd 4,12.16; 16,6; 17,1; 2 Par 27,3; 32,5; 33,14; Ps 50,20.

${ }^{21} \mathrm{O}$ takich próbach mówi m.in. Diodor Sycylijski, wspominając zdławienie oporu mieszkańców Sydonu przeciw perskiemu monarsze, Artakserksesowi (BH 16.44-45), oraz Herodot, pisząc o twierdzy obronnej niejakiego Dejokesa, króla Medów, który chciał zapewnić sobie panowanie, zabezpieczając się przed możliwymi rozruchami w mieście Akbatanie (Hist. I, 98.3-5).

${ }^{22}$ Wysłańcy, mówiąc o wielkości miast ziemi Kanaanu, z nakazu Mojżesza szerzyli defetyzm wśród zgromadzonego na pustyni ludu. Za tym szło nie tylko powszechne niezadowolenie, lecz ponad wszystko niewiara w możliwość zdobycia Ziemi Obiecanej i pomoc Boga, por. R.D. Cole, Numbers. An Exegetical and Theological Exposition of Holy Scripture, NIV NAC 3B, Nashville 2000, s. 222-223.

${ }^{23}$ Pojawia się tutaj ten sam kontekst wiary, lecz w sensie całkowicie przeciwnym do pierwszego z wymienionych cytatów. Oto Kaleb, jedyny obok Jozuego zwiadowca Ziemi Obiecanej, 
dująca była wiara. Należy więc stwierdzić, że zdaniem hagiografa Pierwszej Księgi Machabejskiej, wiary tej zupełnie zabrakło współczesnym mu Żydom, pozbawiającym się nie tylko możliwości zarządzania własną stolicą, lecz odrzucającym również możliwość ponownego władania nią z pomocą swego Boga. Pozwolenie na pogańskie zwierzchnictwo nad miastem wyrażające się akceptacją akry i wzniesionego wokół niej muru jest jaskrawym dowodem na odrzucenie własnego Boga. Natomiast podczas powstania megas kai ochyros przedstawia znaczny obszar miast pogańskich w Ziemi Obiecanej, na które natknął się Juda Machabeusz podczas kampanii w Gileadzie. Wspomniani w w. 5,26 prześladowani przez pogan Żydzi zmuszeni zostali do szukania schronienia w umocnionych i wielkich miastach (poleis ochyrai kai megalai), co jest całkowitym kontrastem sytuacji wzmiankowanej w dwóch pierwszych cytatach, gdy to właśnie Izraelici mieli je zdobywać. Znów okazuje się, że brak wiary oraz wierności Bogu i przymierzu poskutkowały zwycięstwami pogan, jednak ekspedycja militarna Judy zdefiniowana została jako odpowiedź Boga na dramatyczną sytuację Jego ludu ${ }^{24}$. Efron przedstawiony w 5,46 jako miasto wielkie na umocnionym przejściu (polis megale epi tês hodou ochyra), które padnie w walce z wodzem powstańców i jego oddziałami, to przede wszystkim dar od Boga, swoista nagroda za dotychczasową wierność 25 .

Jeszcze jednym, istotnym elementem systemu obronnego twierdzy i miasta były wieże (pyrgoi), wzmacniające same mury i zwiększające możliwości obserwacji okolicy ${ }^{26}$ oraz dające schronienie obrońcom zamku i wszystkim uciekają-

gotów jest ruszyć na wielkie i obwarowane miasta Anakitów wsparty wiarą w pomoc Boga, por. D.M. Howard Jr., Joshua. An Exegetical and Theological Exposition of Holy Scripture, NIV NAC 5, Nashville 1998, s. 329.

${ }^{24}$ Por. J. Nawrot, Pierwsza Księga Machabejska, dz. cyt., s. 699.

${ }^{25}$ W Pwt 1,28 pojawia się zwrot „miasta wielkie i obwarowane” (poleis megalai kai teteichismenai) znów w kontekście strachu ludu przed koniecznością zdobywania ich. Zatem służy ukazaniu potrzeby wiary i pokładania ufności w Bogu wtedy, gdy lud czeka ważne zadanie, por. D.L. Christensen, Deuteronomy 1:1-21:9, Dallas 2001, s. 31. Z kolei w Pwt 6,10 zwrot poleis megalas jest notowany przy okazji Bożego zapewnienia o oddaniu tych miast w ręce ludu, lecz w zamian za wierność prawu i przymierzu, por. E.H. Merrill, Deuteronomy. An Exegetical and Theological Exposition of Holy Scripture, NIV NAC 4, Nashville 1994, s. 169-170. Na koniec Pwt 9,1 to część mowy Mojżesza do ludu zachęcająca do zdobycia wielkich i obwarowanych miast (poleis megalai kai teichēreis) Kanaanu, co zdecydowanie przerastało ludzkie możliwości wędrowców. Sytuacja ta wymuszała zdanie się na pomoc Boga, por. M. Weinfeld, Deuteronomy 1-11. A New Translation with Introduction and Commentary, AB 5, New York-London-Toronto-Sydney-Auckland 1991, s. 405 z odniesieniem do wcześniejszych cytatów księgi. Por. także J. Nawrot, Pierwsza Księga Machabejska..., s. 713.

${ }^{26}$ Według wyroczni Ez 27,11 zadufany w sobie władca Tyru ukazywał okolicznym królom swą wyższość m.in. przez powierzanie warty właśnie na wieżach (pyrgois) strażnikom przyodzianym w ozdobne stroje. Dodawało to miastu splendoru i wspaniałości. Akcent wersetu położony jest na uczestnictwie w obronie miasta obcych, najemnych wojsk opłacanych z kasy bogatego miasta, por. L.C. Allen, Ezekiel 20-48, WBC 29, Dallas 1990, s. 86. Możliwość korzystania z obcych wojsk połączona z bogactwem, umiejscowieniem, obronnością była powodem dumy, która wywołała w końcu gniew Boga. 
cym do niego $\mathrm{w}$ razie ataku ${ }^{27}$. Jeśli wznoszą je poganie, należy postrzegać je jako świadectwo ich pychy i wynoszenia się ponad mieszkających w mieście prawowitych obywateli, jakimi byli Żydzi ${ }^{28}$, oraz znak poniżenia ludu wybranego.

$\mathrm{Z}$ teologicznego punktu widzenia ciekawe jest także końcowe stwierdzenie hagiografa, że miasto stało się twierdzą zarówno dla jego wiernych tradycji religijnej i patriotycznie nastawionych mieszkańców, jak i - paradoksalnie - dla pogan oraz odstępców od prawa i przymierza. W tym przypadku sformułowanie kai egeneto autois eis akran musi być jednak rozumiane w dwóch przeciwstawnych sensach: dla pierwszych stało się twierdzą, ponieważ nie mogą zdobyć go w całości i nie mogą oczyścić go z elementów obcych pod względem religijnym i narodowym. Dla drugich - znakiem zwycięstwa i miejscem schronienia umożliwiającym przetrwanie pośród większości wrogo do nich nastawionych żydowskich mieszkańców stolicy ${ }^{29}$. W płaszczyźnie teologicznej natomiast doszło do sytuacji, w której przeciwstawiający się Bogu i Jego prawu Żydzi oraz poganie zatriumfowali tam, gdzie powinien być On bezwzględnie czczony jako jego Pan i właściwy Gospodarz. Miasto założone przez wiernego Bogu króla Dawida zostało w ten sposób symbolicznie „wykradzione” Jemu samemu oraz Jego ludowi. Cofnęło to historię Jerozolimy, najważniejszego miejsca kultu, do okresu sprzed ustanowienia jej stolicą państwa teokratycznego, zaś pozbawiony jej lud stał się na powrót narodem tułaczym ${ }^{30}$. Nie można przeoczyć, że w kilku ważnych tekstach greckiej Biblii akra łączy się z „miastem Dawida” (polis Dauid) jako siedzibą pałacu króla, który przygotował także podwaliny pod świątynię, miejsce przebywania Boga pośród swego ludu. Są to: 2 Bas 5,9; 3 Bas 10,22a oraz 11,27. W pierwszym z nich informacji o budowie miasta (polis Dauid) i twierdzy $(\text { akras })^{31}$ towarzyszy stwierdzenie, że Pan był z Dawidem i dlatego

${ }^{27}$ Por. 1 Mch 4,60; 5,5.65; 13,33.43; 16,10; 2 Mch 10,18.20.22.36; 14,41; 2 Par 26,15; 32,5; Ps 47,13; Iz 2,15; Ez 26,4.9.

${ }^{28}$ Pozwalającej do czasu odnosić sukcesy, zwłaszcza militarne. Jednak w końcu powodowała ona upadek i ostateczną klęskę tych, którzy nią się charakteryzowali i kierowali, por. J. Nawrot, Pycha króla jako problem teologiczny w 1 Księdze Machabejskiej, PST 24(2010), s. 81-100; tenże: Teologiczne skutki pychy władców i narodów, PST 25(2011), s. 85-106.

${ }^{29}$ Zaimek autois odnosi się chyba nawet bardziej do pogan i odszczepieńców żydowskich z uwagi na bliższy kontekst działań wojsk Apoloniusza (w. 29-32).

${ }^{30} \mathrm{Z}$ tej właśnie racji w myśl 3,46 zebranie patriotów wokół Judy przed bitwą odbyło się w Mispa, dawnym sanktuarium narodu sprzed czasów ustanowienia Jerozolimy stolicą i centralnym miejscem kultu (Sdz 11,11; 20,1.3; 21,1.5.8; $1 \mathrm{Sm}$ 7,5-7.16; 10,17). Hagiograf celowo zaznacza, że spotkanie to przeniesiono do Mispa właśnie z racji niemożności odbycia go w mieście świętym (w. 45). Teksty Jr 40-41 wskazują natomiast, że jeszcze w czasach proroka sanktuarium to funkcjonowało jako miejsce zebrań ludu, choć nie wiadomo, w jakim charakterze, por. O. Lipschitz, The Fall and Rise of Jerusalem: Judah Under Babylonian Rule, Winona Lake 2005, s. 109-112.

${ }^{31} \mathrm{~W}$ oryginale hebrajskim chodzi bardziej o szeroki kanał dzielący fortyfikacje Dawida na miasto górne i dolne lub - co prawdopodobne - fosę napełnioną wodą już w późniejszych czasach Salomona, co zostało antycypowane w obecnym tekście, por. R.W. Klein, I Samuel, WBC 10, Waco 1983, s. 85 . 
wszystko, co przedsięwziął, udawało mu się (w. 10). Drugi tekst wspomina o tym, że Salomon zbudował dom Pana, pałac królewski i cytadelę (akras) zamykającą umocnienia wokół miasta Dawida (poleōs Dauid) ${ }^{32}$, podobnie jak w trzecim z nich (akras... poleōs Dauid, 11,27). Wreszcie, dodatkowo, prorocki cytat Iz 22,9 zapowiada, że wrogowie zajrzą w zakamarki grodu Dawida (akras Dauid) i urządzenia do nawadniania miasta $(\text { polin })^{33}$. Wszystkie prezentowane teksty mają jeden wspólny mianownik: póki dany władca lub społeczność są w wierni Bogu, akceptuje On i wspiera wszelkie działania zmierzające do umocnienia państwa i miasta. Nie wyrazi jednak zgody na podkreślanie własnych umiejętności, czego owocem jest zadufanie w sobie. Całkiem podobną ocenę hagiografa dotycząca postępowania obecnych zwolenników sprzęgnięcia się z pogańskim imperium seleuckim kosztem wierności Bogu Izraela odnaleźć można w analizowanym tutaj fragmencie Pierwszej Księgi Machabejskiej.

\section{Rola załogi zamku według $1,34-38$}

Widać wyraźnie, że w w. 34 wydarzenia przedstawiane są w kategoriach teologicznych. Uwagę czytelnika zwraca przede wszystkim osadzenie (ethēkan) grzesznych pogan (ethnos hamartōlon) w twierdzy przy mieście. Kilka ważnych tekstów rzuca światło na sens zamieszkania pogan pośród Żydów. Oto Ps 43,15 ukazuje skargę kierowaną do Boga, który uczynił (ethou) swój lud przedmiotem przysłów i szyderstw wśród pogan (ethnesin). Bliższy kontekst w. 10-17 opisuje ciagg zniewag, szyderstw i kpin, na jakie narażony został cały Izrael. Jest to dla autora tak szokujące, że nawet nie wie, za jakie nieprawości cierpi cały lud, który chyba nie odszedł aż tak daleko od swego Boga ${ }^{34}$. W Ps 78,1 autor głęboko

\footnotetext{
32 Passus w. 22a-c należy do greckiej wersji Biblii, stanowiąc konkluzję generalizującą dotychczasowych poczynań Salomona i poprzedzająca podobne w tonie zakończenie tekstu hebrajskiego (w. 23-29). Autor grecki uważał widocznie, że samo zakończenie hebrajskie zbyt słabo podkreśla wielkość dokonań syna Dawida, zwłaszcza w relacji do zamieszkujących Ziemię Obiecaną społeczności pogańskich. Te, niewytępione przez Izraelitów, zostały ostatecznie zmuszone do ciężkich prac będących realizacją budowlanych ambicji króla, który w ten sposób oszczędzał własny lud, por. V. Fritz, 1 \& 2 Kings. A Continental Commentary, Minneapolis 2003, s. 135.

${ }^{33}$ Wersety 8b-11a stanowią kontekst bliższy tekstu głównego. Relacjonują bowiem przygotowania do obrony miasta przed najazdem obcych wojsk. Tymczasem oskarżenie hagiografa nie jest spowodowane podjęciem koniecznych skądinąd robót, lecz porzuceniem w ich trakcie z pominięciem Boga, na którym należało się całkowicie oprzeć. W zapowiedzianym czasie poskutkuje to klęską, czyli karą za opieranie się jedynie na własnych umiejętnościach, por. J.N. Oswalt, The Book of Isaiah, Chapters 1-39, NICOT, Grand Rapids 1986, s. 412-413. W Pierwszej Księdze Machabejskiej konkretnym tego przykładem jest porażka oddziałów Józefa i Azariasza w 5,55-62. Omówienie teologicznej oceny postępowania obu postaci dokonanej przez hagiografa, por. J. Nawrot, Teologiczna interpretacja klęski Żydów w 1 Mch 5,55-62, SG 28(2014), s. 6-21.

${ }^{34}$ Cały psalm jest niezwykle trudny do zrozumienia i komentatorzy nie są zgodni co do sensu w. 19-20. Możliwe, że chodzi tu o odstępstwa czynne, lecz z zachowaniem fundamentalnej opcji
} 
ubolewa nad zwycięstwem pogan (ethnē), którzy weszli i zbezcześcili przybytek Pański, a miasto święte obrócili (ethento) w ruinę. Doskonale odpowiada to obecnej sytuacji mieszkańców Jerozolimy, wydanych - jak tamci (w. 2-4) - na pośmiewisko i wzgardę, mordowanych i pozbawianych pochówków ${ }^{35}$. Wyraźnie jest to jednak kara za dotychczasową niewierność Bożym prawom, z czego wynika, że współcześni hagiografowi jerozolimczycy nie wyciągnęli pożądanych wniosków z własnej historii ${ }^{36}$. Podobnie w Hi 17,6, brzmi skarga sprawiedliwego Hioba oskarżającego Boga, że uczynił (ethou) z niego porzekadło wśród narodów (ethnesin) i pośmiewisko dla nich ${ }^{37}$. Podobnie jak w jego przypadku Bóg posłużył się ciagiem nieszczęść, tak w przypadku mieszkańców miasta narzędziami Jego działania są obecnie poganie i renegaci. $\mathrm{Z}$ kolei w Ier 35,14 mowa jest o tym, że Bóg zdecydował (ethēka), iż wszystkie narody (ethnōn), w tym również mieszkańcy królestwa judzkiego, służyć będą królowi babilońskiemu, co będzie znakiem Jego gniewu na całą ziemię. W czasach hagiografa spełnia się więc podobny scenariusz. Na koniec warto przywołać cytat Ez 5,5, gdzie prorok w imieniu Pana mówi o Jerozolimie umieszczonej (tetheika) pośród narodów (ethnōn), przy czym Jego własny lud uznany został za najbardziej bezbożny, ponieważ odrzucił Jego prawa i nie postępował według Jego zaleceń (w. 6) ${ }^{38}$. Nie trzeba uzasadniać, że tę samą ocenę wystawia obecnie hagiograf swym rodakom.

Trudno ustalić, czy kluczowe tu zwroty ethnos hamartōlon oraz andras paranomous oznaczają dwie różne kategorie ludzi czy należy je traktować jako dwa wyrażenia dotyczące jednej grupy ${ }^{39}$. Ponieważ jednak termin ethnos, 'naród' we wszystkich tekstach poprzedzających w. 34 odnosi się wyłącznie do narodów obcych (1,3.4.11.13.14.15), można wnosić, że także obecnie autor natchniony odnosi go do pogan pojmowanych jako bałwochwalcy ${ }^{40}$. Poza tym, jeśliby przy-

na rzecz Boga. Mimo swych odstępstw naród ciagle zachowuje świadomość przynależności do przymierza. Możliwa jest także interpretacja nieszczęść zesłanych przez Boga jako próby wierności narodu, podobnie do Rz 8,36, por. https://www.studylight.org/commentaries/mhm/psalms44.html [dostęp: 09.07.2016].

${ }^{35}$ Por. J. Goldingay, Psalms 2: Psalms 42-89, BCOT: Wisdom and Psalms, T. Longman, Grand Rapids $2007^{3}$, s. 520.

${ }^{36}$ Odrzucając w ten sposób ostrzeżenia kierowane już w mowach Mojżesza, por. J. Nawrot, Teologiczne uzasadnienie wierności przymierzu. Czasowniki šamā i 'āsâ w tekstach prawniczych ST, SG 26(2012), s. 13-22.

${ }^{37}$ Bóg widziany jest tu jako sprawca ostateczny każdego położenia ludzkiego, co wskazuje na sprawstwo pośrednie lub bezpośrednie, por. także R.L. Alden, Job. An Exegetical and Theological Exposition of Holy Scripture, NIV NAC 11, Nashville 1993, s. 190.

${ }^{38}$ Por. D.I. Block, The Book of Ezekiel. Chapters 1-24, dz. cyt., s. 197-198.

39 Józef Flawiusz mówi wprost o frouran Makedonikēn, 'załodze macedońskiej' w twierdzy (Ant. 12.5.4.248). O takich załogach stacjonujących w cytadelach już od czasów Aleksandra Wielkiego pisze również Diodor (tēn akran... systēsas...Makedonas stratiōtas, BH 17.64.5). Ogólniej kwestię tę opisuje Quintus Curtius Rufus (Historiae Alexandri Magni 5.1.43: septingentis Macedonum trecentisque mercede conductis praetores, qui regioni Babyloniae ac Ciliciae praeessent).

${ }^{40}$ Podobnie do Tb 13,8 oraz Ga 2,15. 
miotnikiem hamartōloi definiować Żydów, oznaczałoby to, że zamek musiałby istnieć wyłącznie dla nich, co jest niemożliwe z racji czysto politycznych i strategicznych. Nie można bowiem powierzać strzeżenia interesów imperium tylko tym przedstawicielom okupowanego narodu, którzy go zdradzili. Właściwe bowiem zabezpieczenie swoich interesów gwarantuje dopiero osadzenie własnych regimentów składających się z wiernych królowi żołnierzy ${ }^{41}$. Jeśli więc hamartōloi to poganie, zdecydowanie andres paranomoi to już sami odstępcy żydowscy, poszukujący schronienia w murach zamku ${ }^{42}$. Ci właśnie podlegali pod klątwę passusu Pwt 13,13-17 nakazującego natychmiastową likwidację wszelkiej maści renegatów zapierających się swej wiary i namawiających resztę populacji do odstąpienia od niej ${ }^{43}$. Jeśli jednak obecnie mogą oni działać w zasadzie bez przeszkód, trzeba w tym widzieć Bożą karę wymierzoną pozostałej części społeczności miasta, która dopuściła do takiego stanu rzeczy. Jerozolima stanie się więc miastem przeklętym, wydanym ostatecznie na spustoszenie, jeśli nic się nie zmieni. Szczególnie dobitnie na temat kary Bożej wypowiada się autor, wspominając, że mieszkańcy obwarowali się (enischysan) w zamku. Już niegdyś sam Bóg wzmacniał (enischysen) pogan w walce przeciw swemu niewiernemu ludowi $(\mathrm{Sdz} 3,12-13)^{44}$. Obecnie przeciwnicy powstańców umacniają się w sile i mniemaniu, że postępują dobrze, wyrzekając się zasad przymierza.

O pogorszeniu sytuacji w mieście świadczy też ukazane w w. 35 uzbrojenie zamku, zgromadzona żywność ${ }^{45}$ oraz łupy ${ }^{46}$, co umożliwia przetrwanie najdłuższego nawet oblężenia lub podejmowanie kolejnych, udanych wypadów na miasto lub zwłaszcza teren świątynny. Wzmiankując o gromadzeniu łupów w zamku, autor odnosi się do tekstu Iz 42,22-25, prezentującego Izraelitów jako lud ograbiony i sam wydany na łup. Nie doświadcza on pomocy z zewnątrz, nikt się też za nim

${ }^{41}$ Por. J. Nawrot, Kryzys religijny w Judei za Antiocha IV Epifanesa. Teologia historii w 1 Mch 1,1-2,26, Studia i Materiały 151, Poznań 2012, s. 174-176.

${ }^{42} \mathrm{~W}$ tym znaczeniu także por. 1 Mch 1,$11 ; 6,21 ; 10,61 ; 11,21$, apokryficzny PsSal 12,1 a także Flawiusz (Ant. 12.5.4).

${ }^{43}$ Skrótowe omówienie teologii tekstu, por. D.L. Christensen, Deuteronomy 1:1-21:9, dz. cyt., s. $179-280$.

${ }^{44}$ Komentarz, por. D.I. Block, Judges, Ruth. An Exegetical and Theological Exposition of Holy Scripture, NIV NAC 6, Nashville 1999, s. 157-159. Cytat Jr 9, 2 ukazuje wzmocnienie się niewierności ludu, szerzenie się kłamstwa i hipokryzji, gdy prawda się nie umacnia (ou pistis enischysen), por. omówienie J.R. Lundboma, Jeremiah 1-20. A New Translation with Introduction and Commentary, AB 21A, New York-London-Toronto-Sydney-Auckland 1999, s. 542-543.

${ }_{45}$ Autor bardziej myśli o etapowej aprowizacji fortecy poprzez zagarnianie dóbr żywnościowych okolicznych mieszkańców, o czym wspomina np. w cytat Sdz 6,3-5, por. D.I. Block, Judges, dz. cyt., s. 252-253. W Pwt 28,51 Mojżesz przewiduje możność pożerania przez obcych plonów ziemi uprawianej przez Izraelitów, co ma być karą za niewierność przymierzu.

${ }^{46}$ Łupy, jako efekt plądrowania miasta, stanowią należną zdobywcom część wynagrodzenia za ponoszone trudy walki (w. 31 oraz wcześniej w. 3.19), później zaś stanowią ważny element rozrachunkowy w relacjach ekonomicznych. 
nie ujmie (w. 22). Jest to jednak skutek niewierności prawu Bożemu i świadomego zejścia z Jego dróg (w. 24). Izraelitów trapi ponadto wojna, pożoga, ich miasta są plądrowane (w. 25a-b $\alpha$ ). Tymczasem nikt z ludu nie bierze sobie tego do serca, nikt nie próbuje szukać winy we własnym postępowaniu (w. 25bß). Nikt nie potrafi we właściwy sposób odczytać historii ani obecnych wypadków, dlatego zatwardziałość ludu góruje nad świadomością własnych nieszczęść. Można mieć jedynie nadzieję, że kiedyś dla Izraelitów nadejdzie czas opamiętania ${ }^{47}$. Teologia autora Pierwszej Księgi Machabejskiej aż nadto ukazuje w takim właśnie świetle wszelkie obecne nieszczęścia, jakie dotykają Żydów za czasów Antiocha IV ${ }^{48}$.

Zapis, że przebywający w zamku stali się wielką pułapką (megale pagida), stanowi już generalizującą ocenę całości zaistniałej sytuacji w mieście świętym. Działania mieszkańców akry traktować należy jako nieustanne zastawianie pułapek, zwłaszcza na przybywających do świątyni pielgrzymów ${ }^{49}$. Postępowanie hellenistów przebywających na zamku w Jerozolimie stanowi całkowite przeciwieństwo zakazu podanego przez Jozuego, by Izraelici wchodzący do swego kraju nigdy nie

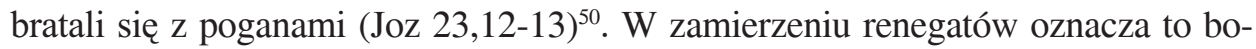
wiem de facto utratę wiary własnej i całego ludu, co jest jednoznacznie przez nich akceptowane, a nawet programowane. Bogate rodziny kapłańskie całkowicie zaprzeczyły misji, do której zostały powołane. Zamiast być strażnikami prawa i dbać o przestrzeganie jego norm przez resztę społeczności, najbardziej zaangażowały się w propagowanie pogańskiego stylu życia. Kolejna prorocka wyrocznia Oz 5,1 akcentuje wspomniane zadania kapłanów i podkreśla, że nie tylko ich nie spełnili, ale doprowadzili do tego, że od Boga odwrócili się biedni, prości ludzie ${ }^{51}$. Również tekst Jr 5,26-27 wspomina o bezwzględności wpływowych członków narodu, którzy bogacą się kosztem nieszczęść biednych ${ }^{52}$. W podobny sposób, odnosząc się do czasów machabejskich, hagiograf ocenia sens polityki bogatych kast kapłańskich, które koncentrują się na zdobywaniu nowych zwolenników poprzez odwodzenie ich od wierności prawom przymierza.

Z w. 36 wynika, że podstawowym zadaniem położonego nieopodal świątyni zamku było zastraszanie mieszkańców i utrudnianie im życia codziennego, zwłaszcza kultycznego, w trakcie odprawiania nakazanych prawem obrzędów. Świątynia, będąc jednak nie tylko miejscem kultu, stanowiła wówczas właściwe

${ }^{47}$ Por. J.N. Oswalt, The Book of Isaiah. Chapters 40-66, s. 133-135.

${ }^{48}$ Wpisuje się to ściśle również w prorocką teologię pogan traktowanych najpierw jako mścicieli prawa Bożego, później jednak tych, którzy sami nie ujdą karze za swe postępki (Iz 10,5-19; Ier 27,1-7; Ez 38,1-18).

${ }^{49}$ Por. 1 Mch 5,4; Oz 5,1; Jr 5,26-27 oraz U. Rappaport, 1 Maccabees, w: The Oxford Bible Commentary, red. J. Barton \& J. Muddiman, Oxford 2001, s. 718; W. Fairweather, J. Sutherland Black, The First Book Of Maccabees: With Introduction and Notes, Cambridge 1897, s. 117.

${ }^{50}$ Por. D.M. Howard Jr., Joshua, dz. cyt., s. 423-424.

${ }^{51}$ Por. D.A. Garrett, Hosea - Joel, dz. cyt., s. 141-143.

${ }^{52}$ Por. J.A. Thompson, The Book of Jeremiah, dz. cyt., s. 249-250. 
centrum żydowskiego życia społecznego czy nawet politycznego w prowincji. Mieszkańcy twierdzy w interesie monarchy imperium dążyli więc do kontrolowania całości życia $\mathrm{w}$ mieście ${ }^{53}$. Sposób działania załogi zamku ukazany został jako zastawianie pułapek lub zasadzek (enedron), czyli jako nagłe wypady w celu, najczęściej, dokonania masakry lub ograbienia pielgrzymów zdążających do świątyni ${ }^{54}$. Podobna w wymowie jest personalizacja zamku jako złośliwego przeciwnika (eis diabolon ponēron), czyli człowieka działającego wbrew woli większości ${ }^{55}$, w tym przypadku całego Izraela. Skutkiem postępowania rezydujących w twierdzy ludzi było niemal całkowite zahamowanie ruchu religijnego pielgrzymów ${ }^{56}$. Ustawiczne nękanie pielgrzymujących (dia pantos) to jednak kara za niewierność samych Izraelitów jeszcze z czasów proroka Jeremiasza $(6,6-8)^{57}$. Wszystko to musiało wpłynąć na teologiczną ocenę hagiografa, podkreślał on bowiem upadek podstawowej funkcji miasta, które niegdyś było centrum religijnym i symbolem wierności prawu całego narodu wybranego ${ }^{58}$. Rozpoczyna się zatem prześladowanie wiernych Bogu Żydów wyrażające się w ataku na świadomość religijną i odrębność kulturową, spójność wspólnoty ${ }^{59}$, a wreszcie w przygotowaniu do prześladowania o charakterze totalnym ${ }^{60}$.

Werset 37 uświadamia przede wszystkim możliwość penetrowania przez pogan obszaru ściśle dotąd rezerwowanego dla członków narodu wybranego ${ }^{61}$. Sposobność

\footnotetext{
${ }^{53}$ Teksty 2 Ezd 4,8-15.19, 1 Es 2,14-18 jednoznacznie wskazują, że Jerozolimę uważano od dawna za buntownicze miasto, a więc takie, które trzeba opanować siłą, co stanowiło jeden z kluczowych wyznaczników polityki seleuckiej, por. W. Fairweather, J. Sutherland Black, The First Book Of Maccabees, dz. cyt., s. 66.

${ }^{54}$ Por. J. Nawrot, Kryzys religijny w Judei, dz. cyt., s. 186-187.

${ }_{55}$ Nie chodzi przy tym o rozumienie diabolos jako istotę duchową przeciwną Bogu (1 Par 21,1; Hi 1-2; Ps 108,6; Mdr 2,24; Za 3,1-2), lecz - za grecką wersją Est 7,4 oraz 8,1 - jako człowieka postępującego niegodziwie, wrogo, z chęcią szkodzenia swym ofiarom, jak Haman, co zgadza się bardziej z kontekstem Pierwszej Księgi Machabejskiej, por. J. Goldingay, Psalms 3: Psalms 60-150, BCOT: Wisdom and Psalms, Grand Rapids 2008, s. 280.

${ }^{56}$ A tym samym niewypełnienia przepisu prawa nakazującego odbywanie takich pielgrzymek, por. Wj 23,17; Pwt 16,16a; 26,2.

${ }^{57}$ Por. P.C. Craigie, P.H. Kelley, J.F. Drinkard, Jeremiah 1-25, WBC 26, Dallas 1991, s. 100.

${ }^{58}$ W szerszym kontekście biblijnym 1 Mch 2,7; 3,45; 2 Mch 1,12; 3 Bas 8,44.48; 2 Par 6,34.38; Tb 13,10; Jdt 5,19; Syr 36,12; 49,6; Iz 8,14; PsSal 8,4; 11,7.

${ }^{59}$ Por. E. Will, C. Orrieux, Ioudaïsmos-hellènismos: essai sur le judaïsme judéen à l'époque hellénistique, Nancy 1986, s. 150-151.

${ }^{60}$ Por. M.F. Baslez, Prześladowania w starożytności. Ofiary - Bohaterowie - Męczennicy, Kraków 2009, s. 132-133.

${ }^{61} \mathrm{Z}$ ewidentnym pogwałceniem przepisu Lb 1,51 o czystości rytualnej. Nota Flawiusza wzmiankuje podobną profanację dokonaną przez króla Heroda, naruszającego zakaz wchodzenia do miejsc przeznaczonych dla kapłanów (Ant. 15.11.5). Traktat Middot Talmudu donosi, że w wewnętrznym murze świątyni znajdowała się okratowana balustrada (tzw. Soreg) na wysokość dziesięciu łokci. W niej to „greccy królowie” uczynili 13 wyłomów (2.3), by móc łatwo dostawać się do wewnętrznych dziedzińców świątyni. Tekst wskazuje zapewne właśnie na działania Antiocha IV, por. J. Goldstein, I Maccabees. A New Translation with Introduction and Commentary, AB 41, Garden City, New York 1976, s. 220.
} 
ta kończyła się częstym przelewaniem niewinnej krwi (eksechean haima athōon) przybywających do świątyni pielgrzymów, co jednak również należy postrzegać jako karę za wcześniejszą niewierność ludu, składającego swe dzieci w krwawych ofiarach na cześć Molocha (Ps 105,38-42) ${ }^{62}$. Rozlana krew utworzyła swoisty okrag wokół domu Bożego (kyklō tou hagiasmatos), co przy uwzględnieniu teologii prawa można postrzegać jako zadośćuczynienie za wcześniejsze grzechy społeczności, obecne wiarołomstwa renegatów oraz uświęcenie ołtarza ${ }^{63}$. Tymczasem poganie nieustannie profanowali (emolynan) świątynię $e^{64}$, podobnie jak odstępujący od prawa synowie Izraela. Gdyby Izraelici pozostali wierni przymierzu, na dziedzińce domu Bożego wchodzono by jedynie, aby wspólnie chwalić Boga ${ }^{65}$.

Warto zwrócić uwagę również na w. 38 akcentujący ucieczkę z miasta patriotów i wiernych prawu Żydów. Ułatwiło to zasiedlenie go przez pogan i zwiększyło szanse odstępców od prawa w konfrontacji z resztą mieszkańców. Opuszczenie miasta przez część Żydów może być odczytywane jako zaniechanie przez nich myśli o czynnym oporze oraz jako świadectwo fatalistycznego przekonania, że sytuacja się nie zmieni. $Z$ drugiej strony jednak ukazuje determinację w wierności przepisom prawa, łącznie $\mathrm{z}$ gotowością do opuszczenia własnych domostw i udania się na tułaczkę. Taki rozwój wypadków to jednak znów smutna konsekwencja realizacji Bożych gróźb wobec niewiernego ludu, zapisanych w Pwt 28, 25. 52 i licznych zapowiedziach Jeremiasza $(8,3 ; 9,15 ; 13,24 ; 18,17 \text {; Ba 2,29 })^{66}$. Gdy hagiograf pisze o cudzoziemcach (allotriōn), myśli chyba - podobnie jak Lm 5,2 zarówno o poganach, jak i żydowskich hellenistach należących co prawda etnicznie do narodu wybranego, lecz postawą dalekich od jego wiary ${ }^{67}$. Miasto stało się tym samym siedliskiem bezprawia i odstępstwa ludu Bożego od przymierza ${ }^{68}$. Wyrażało się to przez uprawianie nierządu z obcymi (theōn allotriōn) bóstwami ${ }^{69}$

${ }^{62}$ Praktyka zawzięcie atakowana przez proroków, por. Jr 2,34; 7,31; 19,4; 22,3.17; 4 Bas 16,3; Ez 16,20 na fundamencie Kpł 18,31 oraz Pwt 12,31, por. także S. Terrien, The Psalms. Strophic Structure and Theological Commentary, CEC, Grand Rapids 2003, s. 731-732.

${ }^{63}$ Krwią ofiar na mocy prawa Mojżesz, Aaron i jego następcy mieli kropić dokoła ołtarz świątynny, por. Wj 29,16; Kpł 1,5.11; 3,2.8.13; 7,2; 8,19.24; 9,12.18; 17,6; Ez 43,20.

${ }^{64}$ Poprzez splamienie rąk krwią (Iz 59,3; 2 Ezd 23,26-27; Jr 23,11), por. F. Hauck, $\mu$ o $\lambda u ́ v \omega$,

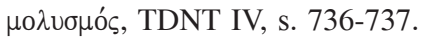

${ }^{65}$ Jak w Ps 78,1, por. J. Goldingay, Psalms 2, dz. cyt., s. 520-521; por. także 1 Es 8,80.

${ }^{66}$ Warto zwrócić przy tym uwagę na teologiczny związek z tekstem Kpł 26,17, który ukazuje Boży gniew jako skutek odejścia od przymierza, wzgardzenia pożytkami wynikającymi z trwania w nim (w. 15), por. J. Milgrom Leviticus 23-36, dz. cyt., s. 2306-2307. Kpł 27,36 traktuje panikę życia codziennego Izraelitów jako stan ,psychicznej dezintegracji”, por. A. Tronina, Księga Kapłańska, NKB ST III, Częstochowa 2006, s. 390.

${ }^{67}$ Por. D. Garrett, P.R. House, Song of Songs/Lamentations, WBC 23A, Nashville 2004, s. 459$-460$.

${ }^{68}$ Por. Oz 11,7; Jr 3,6.8.12; L.C. Allen, Jeremiah. A Commentary, OTL, Louisville-London 2008, s. 56.

${ }^{69}$ Por. Pwt 31,16.18.20; 3 Bas 9,9; 2 Par 28,25; 34,25; Jr 1,16; 5,19; 7,6. 9.18; 11,10; 13,10; 16,$11 ; 19,4.13 ; 22,9 ; 25,6$. 
oraz przez zakłamanie i odrzucenie poznanego wcześniej prawa, które przewyższało wszystkie prawa pogańskie. Autor natchniony eksponuje ludzki ból, gdy prezentuje sytuację wygnania i osierocenia matki przez dzieci oraz dzieci przez matkę. Obraz ten wyraża relację mieszkańców do umiłowanego miasta i najważniejszego dziedzictwa religijnego całego Izraela ${ }^{70}$.

\section{Dotychczasowe walki o akrę według $4,41^{71}$}

Pierwsza Księga Machabejska wspomina o jednej takiej próbie (w. 4,41), którą podjął Juda Machabeusz, to jest na krótko przed oczyszczeniem świątyni i jej ponownym przygotowaniem do sprawowania rodzimego kultu. Zanim jednak skomentowana zostanie decyzja o walce z załogą cytadeli, należy na moment wrócić do krótkiej noty 4,2. Ukazuje ona niekorzystną dla przebiegu powstania rolę garnizonu zamku. Było nią wspomaganie wojsk najeźdźczych w walce z żydowskimi powstańcami poprzez szpiegowanie i ustalanie trasy przemarszu lub sposobu prowadzenia samych batalii. Wywiadowcy z zamku chyba najskuteczniej wspierali armię królewską. Można ich identyfikować z renegatami narodu wybranego, którzy doskonale znali własny kraj, a dzięki znajomości języka rebeliantów zyskiwali informacje o ich planach. Nie potrzeba długich i przekonujących wywodów, by stwierdzić, że załoga zamku mocno dawała się we znaki żydowskim obrońcom ojczyzny ${ }^{72}$.

Według w. 41 zaraz po zakończonym rytuale lamentacyjnym powstańców machabejskich nad świątynią (w. 39-40) należało jednak przejść do konkretnego działania, wykorzystując własną, choć chwilową przewagę oraz brak wsparcia zewnętrznego dla obrońców jerozolimskiej akry ${ }^{73}$. Przewagę tę dały wygrane niedawno bitwy pod Emmaus (4,3-25) oraz Bet-sur (4,20-35). Ich wynik nie wpły-

\footnotetext{
${ }^{70}$ Por. Lm 1,16; 2,19; 3,51; 4,7; Ba 4,16. Symbolika dzieci miasta świętego w Biblii jest dość bogata, i to zarówno w sensie pozytywnym, przedstawiając je jako dzieci, które ostatecznie powrócą do miasta - swej matki (Iz 51,17-18; 60,4.9; Ba 5,5; PsSal 11,2), lecz także dzieci, dla których miasto-matka było niezwykle okrutne, składając je w ofierze bożkom pogańskim (Ez 16,21.36). Niektóre teksty mówią o wierności Bogu przymierza (Iz 54,13) oraz przyszłych zwycięstwach mieszkańców miasta (Ba 4,32; Za 9,13). W Nowym Testamencie najbardziej znanym przejawem tego ujęcia teologicznego jest Mt 23,37, zawierający lamentację Jezusa nad miastem świętym, którego dzieci okazały się tak nieposłuszne orędziu zbawienia, które przyniósł Syn Boży.

${ }^{71}$ Flawiusz sugeruje, że walka z poganami podjęta została równocześnie z pracami odnowicielskimi w świątyni (Ant. XII, 7.6).

${ }^{72}$ Znów Flawiusz potwierdza wprost zdradę żydowskich odstępców (pefeugotōn Ioudaiōn) od przymierza będących przewodnikami (hodēgous) oddziałów Gorgiasza (Ant. 12.7.4.305). Wspieranie przez nich seleuckiego okupanta stało się dodatkowym, lecz ważnym elementem decyzji o walce z mieszkańcami zamku jako jednym z priorytetowych kierunków rozwoju całego powstania. Hagiograf widzi w tym wydarzeniu spełnienie się złowróżbnych zapowiedzi Jr 7, 32-33; 14,16 oraz Ps 78,2-3, por. H.J. Kraus, Psalms 60-150. A Commentary, Minneapolis 1989, s. 134-135; a także Iz 59,7; Lm 4,13; Ez 22,3.6.12.27; D. Garrett, P.R. House, Hosea - Joel, dz. cyt., s. 444.

${ }^{73}$ Poza omawianym szerzej tekstem 1,33-36 jest jeszcze o nich mowa w 2,44; 3,45 oraz 4,2.
} 
nął jednak decydująco na sytuację zamku jerozolimskiego, zaś bliskość świątyni i zamku nie pozwalała na odbudowę domu Bożego i odnowienie kultu bez popadania w konflikt z oddziałami wojsk seleuckich, których zadaniem była kontrola wszystkiego, co działo się na terenie świątyni i - w razie potrzeby - interweniowanie przeciw wszelkim próbom odrodzenia czci Boga Izraela w stolicy. Taka interwencja z punktu widzenia prawa Mojżeszowego stanowiła naruszenie zasady nietykalności przybytku przez pogan i normy dotyczące składania ofiar. W myśl passusu Wj 12,43-49 bowiem żaden cudzoziemiec nie może spożywać żydowskiej paschy, chyba że po dokonaniu obrzezania. To samo akcentuje również tekst Kpł 22,10.13, zaś w. 25 w tym samym rozdziale zakazuje nabywania jakiegokolwiek zwierzęcia od obcych w celu złożenia go w ofierze Bogu. Cytat Lb 3,10 z kolei pod groźbą śmierci zakazuje zbliżania się do progów świątyni wszystkim poza lewitami (por. też Lb 18,4.7). W tradycji prorockiej triumfalnie brzmi zapowiedź Iz 52,1, że żaden nieobrzezany i nieczysty nie wejdzie już w granice miasta świętego. Wreszcie w cytacie Ez 44,9 przypominane zostało z całą stanowczością prawo o zakazie wstępu do domu Bożego kogokolwiek spoza wspólnoty Izraela. Tak więc konieczność walki z pozostającymi w zamku wojskami wynikała zarówno z konkretnego zagrożenia, jakie stanowili dla bezpieczeństwa kultu, jak i z samych nakazów prawa. Obie racje wziął pod uwagę Juda, nakazując walczyć z poganami, pomny także na skutki niedbalstwa swych rodaków już z czasów Ezechiela. Cytat 44,7-8 w księdze proroka wyrzuca niedbałym kapłanom wpuszczenie obcych ${ }^{74}$ do sanktuarium w czasie, gdy składano ofiary nakazane prawem ${ }^{75}$. Jeśli natomiast hagiograf wspomina o nakazie (epetaksen) walczenia (polemein) z poganami, chce poziom patriotyzmu i wierności samego Judy ocenić na równi z tym, który reprezentował Mardocheusz, który przyczynił się do uratowania króla perskiego przed spiskiem jego dwóch eunuchów (Est 1,1a-r). Za tę postawę został on wynagrodzony rozkazem (epetaksen) objęcia stanowiska na dworze królewskim oraz darami $(1,1 q)$. Podobnie Juda zasługuje na nagrodę od samego Boga i całego ludu, ponieważ dba o Jego dom w stolicy.

$\mathrm{Na}$ określenie całości dokonujących się przemian wokół domu Bożego hagiograf użył bardzo ważnego stwierdzenia o oczyszczeniu świątyni (katharisē ta hagia), które z pewnością odpowiada wizji, jaką wcześniej miał Daniel, a którą zanotował w swym dziele, podając w jego pierwotnej, hebrajskiej wersji zwrot niṣdaq qōdeš, co można przetłumaczyć przez 'być przywróconym do swego pra-

${ }^{74}$ Prorok nazywa ich nieobrzezanymi na sercu (aperitmētous kardia) oraz na ciele (aperitmētous sarki), co w drugim przypadku odnosi wprost do pogan, zaś w pierwszym - do Żydów, tylko zewnętrznie przynależących do ludu przymierza, lecz w świetle Jr 4,4 postępowaniem swym hołdującym wartościom pogańskim, zwłaszcza zaś bałwochwalstwu, por. L.C. Allen, Jeremiah, dz. cyt., s. 62; D.I. Block, The Book of Ezekiel. Chapters 25-48, s. 621-624.

${ }^{75}$ Tekst sugeruje niedwuznacznie, że właśnie owi nieobrzezańcy sprawowali ów kult w zastępstwie leniwych i nieodpowiedzialnych kapłanów świątyni, por. L.E. Cooper Jr., Ezekiel. An Exegetical and Theological Exposition of Holy Scripture, NIV NAC 17, Nashville 1994, s. 392-393. 
wowitego stanu świętości' $(8,14)$. Chodzi zatem o restytucję wszelkich praw należnych świątyni, zwłaszcza do sprawowania właściwego kultu, co było niemożliwe po profanacji, jakiej dopuścił się Antioch IV i jego poplecznicy ${ }^{76}$.

\section{Walka o akrę po śmierci Antiocha IV (6,18-20)}

Werset 18 można określić jako nagły zwrot akcji, bezpośrednio po informacji o zejściu z tego świata znienawidzonego władcy seleuckiego, który umarł w Babilonie. Autor bowiem powraca do Jerozolimy, aby usprawiedliwić konieczność ataku powstańców machabejskich prowokacyjnymi działaniami mieszkańców akry, dających się we znaki przybywającym pielgrzymom do odnowionej już i poświęconej świątyni. Nie ulega wątpliwości, że ci, „którzy byli w twierdzy”, to zarówno pogańska załoga zamku, jak i jej żydowscy poplecznicy, odstępcy od prawa ${ }^{77}$. Komentowany obecnie tekst jest nie tylko stwierdzeniem faktu historycznego, lecz celowa kontynuacją zapisu 4,41, w którym zawarta została wzmianka o walkach powstańców z załogą zamku, lecz wówczas bez konkretnego rezultatu. Najprawdopodobniej były to starcia nieudane i zamku ostatecznie nie zdobyto, ograniczono się natomiast do postawienia muru i wież chroniących świątynię oraz pozostawienia tam pewnej części oddziałów w celu chronienia miejsca przed zbezczeszczeniem $(4,60-61)$. Sprowokowało to stacjonujących tam żołnierzy do utrudniania pielgrzymom uczestnictwa w obrzędach na cześć Boga Izraela ${ }^{78}$. Jednakże z powodu radykalnej zmiany sytuacji w mieście świętym po oczyszczeniu przybytku żołnierze z zamku prawdopodobnie nie ośmielali się podejmować dalszych wypadów poza swą siedzibę.

Jeśli jednak przyjmiemy, że Juda i powstańcy opanowali miasto, oczyścili świątynię i obwarowali ją, zwrot sygkleiontes ton Israēl, 'osaczali Izraela' ${ }^{79}$, musi oznaczać podejmowanie pojedynczych, chociaż możliwie częstych wypadów lub dokonywanie ostrzału artyleryjskiego z zamku, co znacząco osłabiało ruch pielgrzymkowy i utrudniało życie mieszkańcom. Użycie czasownika sygkleiō spowodowane jest wspomnianym w w. 19-20 odwetem Judy, czyli oblężeniem i ponownymi próbami zdobycia zamku ${ }^{80}$. Wydaje się też, że stwierdzenie kyklo tōn hagiōn, 'wokół świątyni', jest precyzyjne, ponieważ po opanowaniu jej przez powstańców wejście pogan na jej teren było już niemożliwe. $Z$ tej racji Juda uznał, że pozostawione wcześniej oddziały były niewystarczające, by zapewnić należną ochronę pielgrzymom i mieszkańcom przybytku. Dopełnienie Israēl w kontekście działań mieszkańców zamku przypomina wcześniejszy tekst 1,36

${ }^{76}$ Por. M. Parchem, Księga Daniela, NKB ST, t. XXVI, Częstochowa 2008, s. 536-537.

${ }^{77} \mathrm{Na}$ podstawie wcześniejszych relacji w 1,33; 3,45 oraz 4,2.

${ }^{78}$ Por. J.R. Bartlett, The First and Second Books of the Maccabees, CBC, Cambridge 1873, s. 85.

${ }^{79}$ Różnie od 3,18; 4,31 i 5,5.

${ }^{80}$ Por. B. Bar-Kochva, Judas Maccabaeus: the Jewish Struggle against the Seleucids, Cambridge 2002, s. 299-300. 
opowiadający o niemal całkowitym wymarciu kultu świątynnego z powodu wrogich działań mieszkańców akry. W szerszym znaczeniu dotyczy jednak pobożnych członków narodu wybranego, dla których prawo i przymierze stanowiły najważniejszą część życia religijnego, wiernych i czczących Boga mimo prześladowań ${ }^{81}$. Zwrot dzêtountes kaka, czyli 'szukający (sposobności do czynienia) zła', akcentuje nie tyle nawet najprzeróżniejsze przedsięwzięcia mieszkańców zamku, ile ich nikczemne zamysły ${ }^{82}$. Autor przeprowadza w ten sposób moralną ewaluację ich postępowania, tym bardziej godnego napiętnowania, że działo się ono di' holou, 'przez cały czas', uniemożliwiając faktycznie sprawowanie kultu Bożego. Nie można przy tym zapominać, że ciagle chodzi o czyny zarówno samych pogan, jak i wspierających ich żydowskich odszczepieńców. Wydaje się, że właśnie przede wszystkim im poświęcona jest uwaga hagiografa. Dlatego potrzebna była szybka odpowiedź Judy.

Mimo iż konstrukcja stērigma tois ethnesin, 'wzmocnienie narodom', tylko raz została zastosowana w LXX, być może występuje tutaj jako przeciwieństwo wspomożenia udzielonego wcześniej rebelii Matatiasza przez wygnańców z Izraela $(2,43)$. Stąd nietrudno domyślić się jej znaczenia. Oparciem dla pogan było działanie załogi zamku i hellenistów w tym sensie, że mogli dalej przedsiębrać akcje militarne przeciw powstańcom w sąsiedztwie świątyni i w całym mieście, być wsparciem dla innych wrogów Judy, a ponadto przyspieszyć interwencję wojsk imperialnych w Judei.

Ukazane w w. 19 przedsięwzięcia żołnierzy zamku jerozolimskiego stały się tak bardzo uciążliwe dla pątników zmierzających do świątyni, że Juda musiał zacząć działać. Zadziwia nieco użycie czasownika eksairō, 'wytępić', który do tej pory często używany był jedynie do opisu działania pogan wobec Izraelitów ${ }^{83}$. Zastosowanie go w doniesieniu do walki Judy wobec nich być może ma służyć przekonaniu czytelnika, że nadszedł czas na odwet wobec dawnych ciemiężycieli. Trzeba więc zacząć od załogi zamku sąsiadującego ze świątynią. Prawdopodobniej jednak intencją autora było przedstawienie Judy jako wzorca i przykładu bezkompromisowości dla jego brata, późniejszego arcykapłana Szymona. Przykład Judy miał też mobilizować każdego pobożnego Izraelitę do oporu wobec pogan, którzy poprzez sprawowanie bałwochwalczych kultów nieustannie zagrażali prawdziwej wierze ${ }^{84}$. Byłaby to realizacja zalecenia Pwt 7,1, gdzie sam Bóg zobowiązuje się do wytępienia (eksarei) pogan (ethne) mieszkających w ziemi świętej, którą ma zamiar oddać swemu ludowi. Nie można zapomnieć, że warunkiem wejścia narodu wybranego do Ziemi Obiecanej było usunięcie tych ludów ${ }^{85}$.

\footnotetext{
${ }^{81}$ Por. 1 Mch 1,25.53.58.62; 2,16.42.70; 3,2.15.46; 4,11.25.30-31.59; 5,62.

${ }^{82}$ Por. 1 Bas 25,26; Ps 37,13; 70,13.24.

${ }^{83}$ Por. 1 Mch 3,20.35.45.52.58; 5,2.9.10.27; 6,12.

${ }^{84}$ Ponieważ termin ów określa późniejsze działania militarne wobec pogan $(14,7.14 .36)$

${ }^{85}$ Por. D.L. Christensen, Deuteronomy 1:1-21:9, dz. cyt., s. 156.
} 
Uwzględniając kontekst historyczny, można wątpić, czy Juda posunąłby się do wywołania kolejnego konfliktu $\mathrm{z}$ armią imperialną i zniszczenia tak ważnego punktu władzy i miejsca kontroli regionu, jakim była akra. Nawet jeśli wiedział już o śmierci Antiocha IV i zawirowaniach związanych z regencją małoletniego Antiocha V, mógł się spodziewać, że Lizjasz czym prędzej zechce uporządkować sytuację w Judei, by mieć oczyszczone przedpole do potężnej konfrontacji z Filipem, regentem królestwa $\mathrm{z}$ woli umierającego króla, posiadającym jego diadem, płaszcz i pierścień. Natomiast z teologicznego punktu widzenia Juda chyba popełnił poważny błąd, nie obdarzając swego Boga pełnym zaufaniem ${ }^{86}$ i godząc się na pobyt załogi zamku i odszczepieńców żydowskich między swoim ludem. Wszakże Bóg nakazał wyrzucenie ich z Ziemi Obiecanej. Wódz powstania wykazał się zbyt małym zaufaniem do Tego, który obiecał swe wsparcie w każdej tego typu sytuacji. Powinien zatem zdecydowanie podjąć się swego zadania, a nie kalkulować, co mu się opłaca, a co nie. Już wielokrotnie w historii Izraela poganie stanowili poważne niebezpieczeństwo dla wiary i wierności ludu, co ukazuje zwłaszcza tekst Sdz 2,19-23, ukazujący po raz pierwszy karę za niewierność Izraelitów swemu Bogu. Otóż nie wypędził (eksarai) On obcych ludów (ethnōn) spomiędzy nich, pozwalając, by stały się one próbą dla wierności Izraelitów Bogu i przymierzu ${ }^{87}$. Jak ważnym zadaniem było usunięcie pogan spośród siebie, wskazuje także cytat 3 Bas 14,24, w którym znajduje się wzmianka, że chociaż Pan wytępił (eksēren) pogan (ethnōn) spośród Izraelitów, ci nadal dopuszczali się sakralnego nierządu $\mathrm{z}$ ich bóstwami. Wobec tego karą dla niewiernego ludu była wielka interwencja militarna faraona ${ }^{88}$. Jednakże według 2 Par 7,20 sam Bóg wykorzeni (eksarō) własny lud ze swojej ziemi, a dom, w którym przebywał między Izraelitami, wyda na pośmiewisko i wzgardę ludów (ethnesin) ${ }^{89}$. Zatem przedkładający polityczne kalkulacje wyżej od zaufania Bogu Juda naraził własny lud na kolejne odstępstwa od wierności prawu i przymierzu. Można więc wnioskować, że właśnie $\mathrm{z}$ tego powodu nie był w stanie wypędzić pogan i zwolenników hellenizacji kraju, zarówno wówczas, gdy dokonywał oczyszczenia świątyni, jak i po śmierci Antiocha Epifanesa. Dalsze etapy walki o twierdzę zostają ocenione przez hagiografa jako działania niezdecydowane, może nawet pozorowane. Zabrakło w nich impetu, jaki nadaje siła zaufania do zawsze wiernego swemu ludowi Boga.

${ }^{86}$ W przekonaniu Jr 18,7 Bóg Izraela może całkowicie wyplenić (eksarai) każdy naród (eth$n o s$, który nie pójdzie drogą jego nakazów, por. również L.C. Allen, Jeremiah. A Commentary, dz. cyt., s. 215.

${ }^{87}$ Por. S. Niditch, Judges, OTL, Louisville-London 2008, s. 49-50.

${ }^{88}$ Por. M. Sweeney, I \& II Kings. A Commentary, OTL, Louisville 2007, s. 189. Podobną myśl zawierają także cytaty 4 Bas 16,3; 17,8;21,2; 2 Par 33,9.

${ }^{89}$ Wersety 21-22 stanowią znakomite teologiczne wyjaśnienie powstałej sytuacji z zastosowanym literackim środkiem pytania domyślnego samych winowajców, por. także J.A.Thompson, 1,2 Chronicles. An Exegetical and Theological Exposition of Holy Scripture, NIV NAC 9, Nashville 1994, s. 236. 
Czasownik eksekklēsiadzō, 'zwołać, wezwać na zgromadzenie', pojawia się po raz pierwszy w księdze, przy czym szczególnie bliski wydaje się tu tekst 2 Bas 20,14 . Wspomina on o gromadzeniu się pod dowództwem Joaba Izraelitów, którzy mają zamiar ścigać wroga i zemścić się za jego występki. W tym przypadku chodzi o wewnętrzne porachunki między poszczególnymi pokoleniami izraelski$\mathrm{mi}^{90}$. Po odczytaniu tego wersetu w kontekście $\mathrm{Sdz} 20,1$ oraz 3 Bas 12,2191, można odnieść wrażenie, że wszystkie powyższe teksty sugerują, iż obecna walka Judy o zamek jerozolimski toczy się właściwie między nim a żydowskimi hellenistami, tzn. jest konfrontacją wewnątrzżydowską. Juda zaś po raz kolejny ukazany zostaje na wzór starożytnych bohaterów Izraela. Pas ho laos, 'cały lud', nie oznacza oczywiście wszystkich Izraelitów, lecz jedynie tych, którzy mogli brać udział w walce, a de facto doświadczonych żołnierzy Judy, o których wspomniano już w 5,4392. Jednak zwołanie „całego ludu” może nawiązywać również do podobnego zgromadzenia w sanktuarium w Mispa. Wówczas chodziło o zemstę na bezbożnych pobratymcach, którzy dokonali straszliwej niezgodnej z prawem Izraela zbrodni (Sdz 20,2). Podobnie teraz Juda zwołuje lud celem wyniszczenia tych swoich pobratymców, którzy występuja przeciw prawu Mojżeszowemu i utrudniają kult świątynny. Czasownik perikathizō, 'oblegać', z akcentem na udział całego Izraela należy rozumieć przede wszystkim jako realizację nakazu Pwt 20,12-13, w którym mowa jest o odrzuceniu oferty pokoju proponowanej przez wojska izraelskie oblegające jakieś miasto ${ }^{93}$. Następnie termin ów przybliża prezentowany w. 19 do historycznych działań Jozuego zdobywającego Ziemię Obiecaną ${ }^{94}$. W ten sposób Juda obecnie działa na wzór wielkiego wodza starożytnego Izraela, zaś wszelkie sukcesy gwarantowane są zgodnym udziałem całego ludu w wykonywaniu woli Bożej.

Relacjonowane w w. 20 wykonanie rozkazu wodza naczelnego ukazuje jego niekwestionowany autorytet. Towarzyszy temu świadomość znaczenia swobodnego i bezpiecznego dostępu całego ludu do kultu świątynnego. Rozpoczęcie

${ }^{90}$ Kolejny i jedyny raz jeszcze w 12,35 , w obu przypadkach określając zebranie się ludu w celu dokonania wspólnego dzieła.

${ }^{91} \mathrm{~W}$ pierwszym wersecie mowa jest również o wojnie domowej, poprzedzonej zebraniem ludu w celu podjęcia konkretnych działań bojowych. Z kolei 3 Bas 12,21 wspomina o decyzji Roboama, syna Salomona, by walczyć z pobratymcami królestwa północnego w celu odebrania im własnego, nowo powstałego państwa.

${ }_{92}$ Por. R. Doran, The first book of Maccabees, w: The new interpreter's Bible, red. L.E. Keck, D.L. Petersen, t. 4, Nashville 1996, s. 87.

${ }_{93}$ Por. E.H. Merrill, Deuteronomy, dz. cyt., s. 286.

${ }^{94}$ Por. 10,31.34.36.38 jako forma wojny błyskawicznej, literacko przedstawiona stałym schematem: wyruszył z miasta X - dotarł do miasta $\mathrm{Y}$ - oblegał je - zdobył. Warto przy tym zaznaczyć, że oblężenia te były zwycięskie z uwagi na bezwzględną wierność naczelnego wodza i jego oddziałów prawu Bożemu. Oznacza to, że sam Bóg staje się gwarantem zwycięstw, jeśli lud Go słucha i realizuje Jego wolę, por. S. Wypych, Księga Jozuego, NKB, Częstochowa 2015, s. 270-272; por. także 3 Bas 16,17 . 
oblężenia nastapiło wiosną 163 roku przed $\mathrm{Chr} .{ }^{95}$ lub jesienią tego samego roku, ponieważ autor nie precyzuje miesiąca ${ }^{96}$. Częśś badaczy twierdzi, że chodzić może o wiosnę roku $162^{97}$, w zależności od przyjętej daty rozpoczęcia ery seleuckiej w kalendarzu greckim.

Swoistym novum $\mathrm{w}$ dotychczasowym opowiadaniu autora jest podanie szczegółów oblężenia. Użycie profesjonalnego sprzętu wojskowego do tego typu działań bojowych świadczy o wzroście umiejętności prowadzenia walki przez powstańców. Być może wiązało się to z udziałem pewnej części żydowskich weteranów wojennych, którzy służyli uprzednio w armii seleuckiej i znali się na zastosowaniu takich urządzeń. Dołączyli oni teraz do powstańców i byli bardzo cenną częścią oddziałów Judy ${ }^{98}$. W myśl 5,30 Juda i jego wojska miały okazję zapoznać się z funkcjonowaniem takich machin podczas walki o zdobycie twierdzy Datema, dzięki czemu obecnie mogli skutecznie przeciwstawić się armii seleuckiej99. Termin belostasis, 'bateria', jako miejsce do ustawienia kuszy wojennej pojawia się po raz pierwszy. Według opinii badaczy chodzić może o jakiś rodzaj taranów bombardujących lub platform zbudowanych ze zwartej ziemi lub kamieni, na których stawiano machiny i wyrzutnie ${ }^{100}$. Chodziło więc zapewne o szeroką, grubą belkę zakończoną żelaznym okryciem, przypominającą czasem barani łeb. Belka ta była zawieszona na mocnych powrozach przyczepionych do słupów. Balansowała w przód i w tył, pchana siłą mięśni na mur. Podczas ataku na mur miasta lub fortu pierwszym krokiem było uformowanie odpowiednio nachylonej powierzchni lub nasypu ziemi w celu zwiększenia siły rażenia ${ }^{101}$. O mēchanai wspomina już 5,30 jako o urządzeniach oblężniczych wojsk greckich, przeznaczonych przede wszystkim do kruszenia murów twierdzy ${ }^{102}$. Można

${ }^{95}$ Por. J.R. Bartlett, 1 Maccabees w: Eerdmans Commentary on the Bible, red. J.D.G. Dunn, J.W. Rogerson, Grand Rapids 2003, s. 816.

${ }^{96}$ Por. A.P. Spilly, 1 Maccabees, w: The Collegeville Bible Commentary: Based on the New American Bible: Old Testament, red. D. Bergant, Collegeville 1992, s. 380.

${ }^{97}$ Por. B. Bar-Kochva, Judas Maccabaeus: the Jewish Struggle against the Seleucids, Cambridge 2002, s. 301; J. Goldstein, I Maccabees, dz. cyt., s. 315; R. Doran, The first book of Maccabees, dz. cyt., s. 87.

${ }^{98}$ Por. U. Rappaport, 1 Maccabees, dz. cyt., s. 720.

${ }^{99}$ Por. J.R. Bartlett, The First and Second Books of the Maccabees, dz. cyt., s. 85.

${ }^{100}$ Termin ów w LXX odpowiada hebr. dājēq w BH, oznaczającemu wały usypane przez oblegających, aby nie dopuścić do wchodzenia lub opuszczania oblężonego miejsca przez obrońców (2 Krl 25,1; Jr 52,4). Jednak z racji 1 Mch 6,51, gdzie belostasis pojawia się w złożeniu z czasownikiem istēmi, 'po-/ustawić', jako odpowiednikiem hebr. rdzenia ' $m d$, który nie odnosi się do budowania, należy belostaseis odnieść raczej do hebr. kārîm, oznaczającego 'tarany' (Ez 4,2; 21,27; por. L. Koehler, W. Baumgartner, J.J. Stamm, Wielki słownik hebrajsko-polski i aramejsko-polski Starego Testamentu, red. P. Dec, PSB, Warszawa 2008, s. 467.

${ }^{101}$ Por. http://www.biblestudytools.com/dictionaries/smiths-bible-dictionary/battering-ram.html [dostęp: 18.07.2016]; B. Bar-Kochva, Judas Maccabaeus, dz. cyt., s. 301.

${ }^{102}$ Rzeczownik ów jest prawdopodobnym tłumaczeniem hebr. hišb̄ōnôt, obecnego w 2 Krn 26,15, chociaż funkcjonującego w zupełnie innych czasach biblijnych, por. B. Bar-Kochva, Judas Maccabaeus, dz. cyt., s. 319-320. 
je scharakteryzować jako dość skomplikowane, potężne machiny artyleryjskie przeznaczone do zdobywania obleganych twierdz i fortec, co sugeruje w. 51 podający następnie szczegółowe ich rodzaje $\mathrm{e}^{103}$.

Zaznaczając, że oblężenie nie skończyło się sukcesem, autor subtelnie ukazuje teologię porażki, która historycznie niewątpliwie miała miejsce. Juda nie zdobył akry, a wkrótce potem musiał zgodzić się na upokarzający rozejm. Hagiograf wspomina o rozpoczynającej się serii porażek tego bohatera ocenianych jako skutek słabnącej wierności Bogu, co wyraża się tutaj zwłaszcza przez odejście od bezwzględnego wypełniania Jego postanowień zawartych w prawie Mojżeszowym ${ }^{104}$. Kulminacją opisywanych zdarzeń będzie zawarcie przymierza z pogańskim Rzymem (1 Mch 8). Od finalnej przegranej uratuje go zwrot sytuacji w państwie seleuckim wraz z pojawieniem się Filipa, nowego regenta imperium, w stolicy państwa ${ }^{105}$.

\section{Theological Picture of the Fortress of Jerusalem in 1 Maccabees 1,33-38 and Its Siege by the Army of Judah in 4.41 and 6,18-20}

\section{Summary}

The purpose of this article is to present certain episodes of the acts of war of insurgent army under the leadership of Judah Maccabee, which occurred both before the death of Antiochus IV Epiphanes, the biggest enemy of Jews in Seleucia empire, and shortly after it. The undertaken efforts clearly show that even after the death of the hated ruler the situation in the province of Judah has not changed radically. The insurgents still attempted to free themselves from Seleucia rulers, whose castle in the capital was probably the most important sign of domination. To understand the meaning of the activities of insurgents better one cannot ignore the role that acre played in oppressing the chosen people. The first part of the article mentions that. An important final query, however, is an attempt to answer the question of the author of the book - why did Judah fail to take the fortress, despite undoubtedly favorable circu mstances surrounding it. The article deals with the First Book of Maccabees, which is still rarely commented, as well as all deuterocanonical books, more often overlooked in exegetical discussions than books of the Hebrew Bible.

${ }^{103}$ Flawiusz w swej relacji używa bliskoznacznego terminu mēchanēmata oraz chōmata, opisując drugim z terminów szańce lub nasypy ziemne (Ant. 12,9.3.363).

${ }^{104}$ Juda nie wziął przykładu z prezentowanych w przedśmiertnej mowie jego ojca, Matatiasza, wielkich postaci historii Izraela, odznaczających się przede wszystkim wiernością Bogu i Jego prawu, por. J. Nawrot, Teologiczna symbolika wybranych postaci $w$ historii Izraela w mowie Matatiasza (1 Mch 2,51-61), PST 29 (2015), s. 119-134. Warto rozwinąc tutaj aspekt postępowania bohatera biblijnego jako wzorca ludzkich zachowań niezależnie od czasów, w których żyją, na co uwagę zwrócił Benedykt XVI w adhortacji Verbum Domini, por. J. Nawrot, Miejsce i rola Starego Testamentu, dz. cyt., s. 79-80, 84 .

${ }^{105}$ Warto też zauważyć, że ten sam schemat wydarzeń notuje autor w późniejszych działaniach Jonatana wobec zamku w Jerozolimie, notabene również nierozstrzygniętych: oblężenie twierdzy poselstwo obrońców do króla i jego interwencja w obronie oblężonych $(11,20-22)$. Wydaje się jednak, że w tym przypadku Bóg poddał próbie swego wybrańca, by ten ufał Mu mimo różnych niesprzyjających okoliczności. 


\section{Keywords}

Biblical exegesis, Old Testament, deuterocanonical books, The First Book of Maccabees, Antiochus IV Epiphanes, Judas Maccabaeus

\section{Bibliografia}

Alden R.L., Job. An Exegetical and Theological Exposition of Holy Scripture, NIV NAC 11, Broadman \& Holman Publ., Nashville 1993.

Allen L.C., Ezekiel 20-48, WBC 29, Word Books Publ., Dallas 1990.

Allen L.C., Jeremiah. A Commentary, OTL, The Westminster John Knox Press, Louisville-London 2008.

Bar-Kochva B., Judas Maccabaeus: the Jewish Struggle against the Seleucids, Cambridge University Press, Cambridge 2002.

Bartlett J.R., The First and Second Books of the Maccabees, CBC, Cambridge Univ. Press, Cambridge 1973.

Bartlett J.R., 1 Maccabees, w: Eerdmans Commentary on the Bible, red. J.D.G. Dunn, J.W. Rogerson, W.B. Eerdmans Publ. Comp., Grand Rapids 2003, s. 807-830.

Baslez M.-F., Prześladowania w starożytności. Ofiary - Bohaterowie - Męczennicy, WAM, Kraków 2009.

Block D.I., Judges, Ruth. An Exegetical and Theological Exposition of Holy Scripture, NIV NAC 6, Broadman \& Holman Publ., Nashville 1999.

Block D.I., The Book of Ezekiel. Chapters 1-24, NICOT, Eerdmans Publ. Comp., Grand Rapids-Cambridge 1997.

Block D.I., The Book of Ezekiel. Chapters 25-48, NICOT, Eerdmans Publ. Comp., Grand Rapids-Cambridge 1998.

Bowen N.R., Ezekiel, w: The Oxford Encyclopedia of the Books of the Bible, t. 1, red. M.D. Coogan, Oxford 2011, s. 282-300.

Christensen D.L., Deuteronomy 1:1-21:9, WBC 6A, Word Books Publ., Dallas 2001.

Cole R.D., Numbers. An Exegetical and Theological Exposition of Holy Scripture, NIV NAC 3B, Broadman \& Holman, Nashville 2000.

Cooper L.E. Jr., Ezekiel. An Exegetical and Theological Exposition of Holy Scripture, NIV NAC 17, Broadman \& Holman, Nashville 1994.

Craigie P.C., Kelley P.H., Drinkard J.F., Jeremiah 1-25, WBC 26, Word Books Publ., Dallas 1991.

Doran R., The first book of Maccabees, w: The new interpreter's Bible, red. L.E. Keck, D.L. Petersen, t. 4, Abingdon, Nashville 1996, s. 1-178.

Fairweather W., Sutherland Black J., The First Book Of Maccabees: With Introduction and Notes, The University Press, Cambridge 1897.

Fritz V., 1 \& 2 Kings. A Continental Commentary, Fortress Press, Minneapolis 2003.

Garrett D.A., Hosea - Joel. An Exegetical and Theological Exposition of Holy Scripture, NIV NAC 29, Broadman \& Holman Nashville 1997.

Garrett D., House P.R., Song of Songs/Lamentations, WBC 23A, Th. Nelson Publ., Nasville 2004.

Goldingay J., Psalms 2: Psalms 42-89, BCOT: Wisdom and Psalms, T. Longman III (wyd.), Baker Academic, Grand Rapids 2007. 
Goldingay J., Psalms 3: Psalms 60-150, BCOT: Wisdom and Psalms, T. Longman III (wyd.), Baker Academic, Grand Rapids 2008.

Goldstein J., I Maccabees. A New Translation with Introduction and Commentary, AB 41, Doubleday \& Co., Garden City, New York 1976.

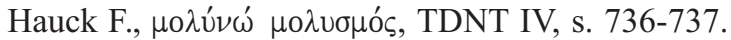

Howard D.M. Jr., Joshua. An Exegetical and Theological Exposition of Holy Scripture, NIV NAC 5, Broadman \& Holman, Nashville 1998.

Klein R.W., I Samuel, WBC 10, Word Books Publ., Waco 1983.

Koehler L., Baumgartner W., Stamm J.J., Wielki słownik hebrajsko-polski i aramejsko- polski Starego Testamentu, red. P. Dec, PSB, Vocatio, Warszawa 2008.

Kraus H.J., Psalms 60-150. A Commentary, Augsburg Publ. House, Minneapolis 1989.

Lipschitz O., The Fall and Rise of Jerusalem: Judah Under Babylonian Rule, Eisenbrauns, Winona Lake 2005.

Loria, B.Z., The Location of the Akra - North of the Temple Mount, "Yad Yizthak Ben-Zvi" 18 (1981), s. 31-40.

Lundbom J.R., Jeremiah 1-20. A New Translation with Introduction and Commentary, AB 21A, Doubleday, New York-London-Toronto-Sydney-Auckland 1999.

Mazar B., The Mountain of the Lord, Doubleday \& Company, Garden City 1975.

Merrill E.H., Deuteronomy. An Exegetical and Theological Exposition of Holy Scripture, NIV NAC 4, Broadman \& Holman, Nashville 1994.

Milgrom J., Leviticus 23-36. A New Translation with Introduction and Commentary, AB 3B, Doubleday, New York-London-Toronto-Sydney-Auckland 2000.

Nawrot J., Jaka rolę odgrywaja starsi Izraela w tekstach przedstawiajacych epokę Mojżesza, PST 27(2013), s. 117-138.

Nawrot J., Kryzys religijny w Judei za Antiocha IV Epifanesa. Teologia historii w 1 Mch 1,1-2,26, Studia i Materiały 151, WT UAM, Poznań 2012.

Nawrot J., Miejsce i rola Starego Testamentu w adhortacji Benedykta XVI Verbum Domini (na przykładzie stosowanych cytacji), PST 26(2012), s. 57-85.

Nawrot J., Pierwsza Księga Machabejska, rozdziały 1,1 - 6, 16, NKB XIV/1, Częstochowa 2016.

Nawrot J., Pycha króla jako problem teologiczny w 1 Księdze Machabejskiej, PST 24(2010), s. 81-100.

Nawrot J., qin'â jako pozytywna motywacja ludzkiego działania w Starym Testamencie, SG 24(2010), s. 43-59.

Nawrot J., Teologiczna interpretacja klęski Żydów w 1 Mch 5, 55-62, SG 28(2014), s. 5-21.

Nawrot J., Teologiczna symbolika wybranych postaci $w$ historii Izraela $w$ mowie Matatiasza (1 Mch 2, 51-61), PST 29(2015), s. 117-138.

Nawrot J., Teologiczne skutki pychy władców i narodów, PST 25(2011), s. 85-106.

Nawrot J., Teologiczne uzasadnienie wierności przymierzu. Czasowniki šamā i 'âsâ w tekstach prawniczych ST, SG 26(2012), s. 5-23.

Nawrot J., Wyprawa Antiocha IV na wschód imperium $w$ teologicznej relacji 1 Mch 6, 1-4, SG 29(2015), s. 119-141.

Niditch S., Judges, OTL, The Westminster John Knox Press, Louisville-London 2008.

Oswalt J.N., The Book of Isaiah. Chapters 1-39, NICOT, Eerdmans Publ. Comp., Grand Rapids 1986.

Oswalt J.N., The Book of Isaiah. Chapters 40-66, NICOT, Eerdmans Publ. Comp., Grand Rapids 1998. 
Parchem M., Księga Daniela, NKB ST, t. XXVI, ed. Św. Pawła, Częstochowa 2008.

Propp W.H.C., Exodus 19-40. A New Translation with Introduction and Commentary, AB 2A, Doubleday, New York-London-Toronto-Sydney-Auckland 2006.

Rappaport U., 1 Maccabees, w: The Oxford Bible Commentary, red. J. Barton \& J. Muddiman, Oxford Univ. Press, Oxford 2001, s. 711-734.

Spilly A.P., 1 Maccabees, w: The Collegeville Bible Commentary: Based on the New American Bible: Old Testament, red. D. Bergant, Liturgical Press, Collegeville 1992, s. $370-395$.

Sweeney M., I \& II Kings. A Commentary, OTL, Westminster John Knox Press, Louisville 2007.

Terrien S., The Psalms. Strophic Structure and Theological Commentary, CEC, Eerdmans Publ. Comp., Grand Rapids 2003.

Thompson J.A., 1,2 Chronicles. An Exegetical and Theological Exposition of Holy Scripture, NIV NAC 9, Broadman \& Holman Publ., Nashville 1994.

Thompson J.A., The Book of Jeremiah, NICOT, Eerdmans Publ. Comp., Grand Rapids 1980.

Tronina A., Księga Kaptańska, NKB ST III, Ed. Św. Pawła, Częstochowa 2006.

Tsafrir Y. The Location of the Seleucid Akra in Jerusalem, Yad Yizthak Ben-Zvi 14(1980), s. $17-40$.

Weinfeld M., Deuteronomy 1-11. A New Translation with Introduction and Commentary, AB 5, Doubleday, New York-London-Toronto-Sydney-Auckland 1991.

Will E., Orrieux C., Ioudaismos-hellènismos: essai sur le judaisme judéen à l'époque hellénistique, Presses universitaires de Nancy, Nancy 1986.

Wypych S., Księga Jozuego, NKB VI, Częstochowa 2015.

\section{Skróty zastosowane $\mathrm{w}$ pracy}

$\mathrm{AB}$ - The Ancor Bible

Ant. - Józef Flawiusz, Antiquitates Judaeorum

BCOT - Baker Commentary on the Old Testament

BH - Diodor Sycylijski, Bibliotheca Historica

BH - Biblia Hebrajska

CBC - The Cambridge Bible Commentary

CEC - Critical Eerdmans Commentary

Hist. - Herodot, Historiae

LXX - Septuaginta

NICOT - New International Commentary on the Old Testament

NIV NAC - New International Version - New American Commentary

NKB ST - Nowy Komentarz Biblijny, Stary Testament

OTL - Old Testament Library

PSB - Prymasowska Seria Biblijna

PsSal - Psalmy Salomona

PST - Poznańskie Studia Teologiczne

SG - Studia Gnesnensia

TDNT - Theological Dictionary of the New Testament

WAM - Wydawnictwo Apostolstwa Modlitwy

WBC - Word Biblical Commentary

WT UAM - Wydział Teologiczny UAM Poznań 